\title{
New Divisions of Labour?: Comparative Thoughts on the Current Recession
}

\author{
by Graham Crow, Peter Hatton, Dawn Lyon and Tim Strangleman \\ University of Southampton; University of Kent; University of Kent; University of Kent
}

\author{
Sociological Research Online, Volume 14, Issue 2, \\ < http://uww. socresonline.org.uk/14/2/10.html> \\ doi:10.5153/sro. 1929
}

Received: 11 May 2009 Accepted: 26 May 2009 Published: 30 May 2009

\begin{abstract}
This article argues that it is useful to compare the current recession with that which occurred three decades ago. Drawing on research undertaken at that time by Ray Pahl, it is suggested that four questions are once again revealing in the study of the current economic downturn: 'How have we come to be where we are currently?', 'Who gets what?', 'How do we know what we claim to know?', and 'What sorts of lessons can be drawn to inform thinking about the future?' The usefulness of asking these questions is discussed, even though the answers must await further research.
\end{abstract}

\section{Keywords: Recession, Divisions of Labour, Community}

\section{Introduction}

1.1 Any sociological perspective on the current recession involves comparisons, since sociology is an inherently comparative discipline. These comparisons may involve sociological variables (such as the uneven impact of the recession on different social classes and genders) but can also be across time and space. We can learn much from how the current situation compares to former economic downturns, or from the differential impact of economic change between countries and regions. A good place to start is to consider existing sociological research, and how far that still applies to the current situation and, where it does not, how and why things have changed.

1.2 One obvious point of reference is the extensive sociological writing on the economic crisis that ran for a decade from the mid-1970s. Sociologists produced extensive material analysing the causes and consequences of that recession, in particular the impact of unemployment and economic insecurity on workers and their families and communities. A short article cannot consider more than a small part of this literature, but we seek to illustrate the usefulness for understanding the present of taking previous research as a point of comparison by focusing on one case: that of the research undertaken by Ray Pahl and his team on the Isle of Sheppey in Kent during the later 1970s and early 1980s.

1.3 The selection of the research of Pahl and his team to illustrate the value of comparison between the present and the past reflects the wide-ranging agenda of that research and its impact, judged for example by its high citation (Halsey 2004: 176). The set of questions that were asked about Sheppey three decades ago remain pertinent today, even though then, as now, Sheppey cannot be considered in any sense 'typical' or 'representative' of wider populations. We have identified four questions from among those that were explored by Pahl and colleagues as particularly useful.

\section{Question 1: 'How have we come to be where we are currently?'}

2.1 In the case of Sheppey, the centuries-old reliance on employment in the naval dockyard at Sheerness meant that when it was closed in 1960 the occupational community that had built up around it was left exposed. Other employment opportunities did develop, but the local labour market was characterised by heightened vulnerability to fluctuating economic conditions. The trajectory of local patterns of employment cannot be understood fully without knowledge of the legacy of the dockyard, and much of Pahl's (1984) Divisions of Labour (the single most important publication to arise from the Sheppey research) was devoted to chronicling this history.

2.2 If we follow this lead when analysing the current recession, we can note various similarities and differences in how we have come to be where we are. One similarity is that both have come as something 
of a surprise to those who grew accustomed to a prolonged period of rising prosperity. An obvious difference is that the intervening thirty years have seen the de-industrialization of the UK economy taken much further, and a corresponding rise in service sector employment.

2.3 There has been a related shift in the profile of the workforce, most obviously in its 'feminization' as the 'traditional' prominence of the full-time male manual worker has given way to the more 'flexible' patterns of the post-industrial, post-Fordist economy. The 'portrait of an industrial island' (Pahl 1984: ch.6) that Pahl painted would now be re-framed more in terms of a post-industrial landscape, but the point remains that economic legacies from former patterns of employment leave their mark for long periods. A particularly cruel aspect of this fact is the beleaguered position of older workers over the age of 45 who have trained for particular roles that they have spent their working lives performing, only to find themselves 'redundant' and short of options to retrain (Loretto et al 2007).

\section{Question 2: 'Who gets what?'}

3.1 This pithy formulation was used by Westergaard (1995) in relation to class inequalities, but it can be applied to all dimensions of social stratification. In the case of Sheppey, social polarization between the 'work-rich' and the 'work-poor' was a notable feature of the impact of the recession that took hold in the late 1970's, but this was about age as well as about social class. Claire Wallace's (1987: 140) research into the transition from education to the labour market identified two contrasting trajectories, those of 'swimmers' and 'sinkers' reflecting the presence of polarization among young people. The lives of those young people able or unable to secure regular employment were poles apart. Pahl's analysis of adults highlighted a similar cleavage, which was exacerbated rather than modified at the household level because of how the system of welfare benefits operated. It was also reinforced by the operation of the housing market, where a widening gap between owner-occupiers and tenants was observable.

3.2 These issues remain pertinent in the current situation where unemployment is unevenly distributed across age groups (concentrated among younger and older people) and geographical areas, notwithstanding that areas formerly dependent on financial services employment are now feeling the effects of economic restructuring. The concentration of the adverse effects of economic downturns mean that certain groups come through relatively unscathed, such as those in secure employment and advantageous housing situations.

3.3 One feature of Pahl's interest in occupational communities was the fact that these communities were seen to be on the point of profound and far-reaching change and in terminal decline, and were populated therefore with almost pure traditional workers. Lockwood (1975: 20) discusses the trend in his seminal essay on the fate of traditional proletarian and deferential workers who were increasingly 'found in industries and communities' which were, as he put it, 'backwaters of national industrial and urban development'. Such workers were being displaced, or had already been so, by a new kind of worker with instrumental orientations to work, their commitment narrowly defined by the cash nexus.

3.4 As part of this discussion Graeme Salaman (1974) drew attention to the classed nature of occupational communities. In his comparative study of railway workers and architects he noted amongst other things the homogeneous residential settlement of the former compared to the far more diffuse patterns of the latter. The point here is that middle class occupations and professions tend not to be grouped in homogeneous settlements such as factory towns and industrial districts, thus a downturn amongst white collar employment is felt very differently from that of traditional manual occupations.

3.5 In the 1970s Pahl had thought that people marginalised in the formal labour market might turn instead to the informal economy, but his research findings disabused him of this notion. What they confirmed instead was that alternative ways of getting by in difficult economic times still require access to resources as well as to time. The finding of Jahoda and her colleagues' (1972) classic study of unemployment in 1930s Austria, that unemployed people have very few opportunities, appears to be confirmed in many different contexts.

\section{Question 3: 'How do we know what we claim to know?'}

4.1 There were two dimensions to this, conceptual and methodological. Conceptually the Sheppey research set about examining the very idea of 'work' in all its forms, including those beyond formal employment contracts such as domestic self-provisioning. The argument was advanced that this broader analytical framework allowed much more sense to be made of the household work strategies that people developed than conventional understandings were able to provide.

4.2 This line of thinking has been developed in Miriam Glucksmann's Total Social Organisation of Labour theory (TSOL), formulated to conceptualise the connections between work undertaken in diverse socio- 
economic spaces (paid and unpaid, formal and informal) (Glucksmann, 1995; further elaborated in Glucksmann, 2006). Pahl also argued that conventional understandings of social class which contrasted working-class and middle-class patterns failed to capture the realities of an emerging 'middle mass' (1984: 320 ) that straddled this divide. Wallace further identified the need to re-think the meaning of 'employment careers', 'marriage' and 'family' (1987: 228).

4.3 This urge to reconsider received wisdom was complemented by pioneering use of mixed methods. Sheppey was researched by a combination of a large survey, qualitative interviewing, ethnographic observations and documentary analysis. The team also drew on a range of disciplines besides sociology, including anthropology, history, political economy and social policy analysis.

4.4 The pertinence of these points for the current situation lies less in their specifics and more in their imaginativeness. The current economic situation directs our attention not only to the meaning of work but also to the meaning of 'money', given that the banking crisis has undermined trust in investments that were purported to be of more 'value' than transpired. This brings to mind a comment made on an economic crisis much longer ago, that of 1848: 'all that is solid melts into air' (Marx and Engels 1973: 70). The renewed interest in the sociology of money reaffirms the value of previous analyses undertaken in this field, from Simmel's classic study first published in 1907 (Simmel 1990) to Zelizer's (1997) The Social Meaning of Money.

4.5 Similarly it is crucial that the methods employed in the analysis of the current economic situation are adequate to capturing the characteristics of the contemporary world (Urry 2007). There are crucial, if unexpected, ways in which the current crisis tells us something about the meaning of work and money. Since the Sheppey study was undertaken the literature on deindustrialisation has matured. Arguably this field is far more extensive in the context of the USA where scholars, taking their lead from Bluestone and Harrision's (1982) classic The Deindustrialization of America, have explored the experience of job loss on individuals, families, communities and whole regions (Dudley 1994; Luxton and Corman 2001; Linkon and Russo 2002; Cowie and Heathcott 2003).

4.6 This literature reveals that in the context of worklessness we come to understand more fully the complex ways in which we are attached to the work we do. Unemployment and deindustrialisation act as a large-scale Garfinkelian 'breaching experiment' wherein the loss of a previously unreflected upon aspect of life forces people to consider what they took for granted (Ezzy 2001). Connected with this is a, some would say nostalgic, lament for the loss of 'real' tangible jobs and their fleeting replacement by intangible service sector employment in an economy based on speculation. This desire is often heard in interviews with displaced workers; in Bamberger and Davidson's (1999) evocative Closing: the life and death of an American factory the epilogue 'Does Anybody Make Anything Anymore?' reflects workers' fears not simply for the loss of their own jobs but the fate of a wider society no longer engaged in production.

\section{Question 4: 'What sorts of lessons can be drawn to inform thinking about the future?'}

5.1 Uncertainty about what we know leads on to uncertainty about the future. Pahl's injunction to connect the sociological analysis of the private troubles of people's lives with the policy field of public issues was a deliberate echo of Mills' call in The Sociological Imagination (Mills 1970). This provides a useful reminder that sociology has an important role in exposing the traps into which many people may fall, and how their biographies turn out differently from how they were imagined.

5.2 One particularly interesting feature of the Sheppey research was Pahl's (1978) collection of data in the form of essays in which young people approaching the end of their time in school were asked to write an essay imagining their lives from the vantage point of thirty or forty years time, which, as chance has it, is the present time. Such material is interesting in and of itself for what it tells us about people's aspirations, but it is also a fascinating point of comparison with data relating to the reality of those people's lives, as Elliott (2005) has shown. There are interesting parallels with the restudy carried out by Goodwin and O'Connor (2005) who carried out a large-scale re-evaluation of Norbert Elias' study of young people's transition into work in the early 1960's and includes subsequent work life histories of some of the sample who are now at the end of their working lives. There are other examples of restudies of classic research examining youth/work transitions including Linda McDowell's (2003) Redundant Masculinities?, and Dolby and Dimitradis (2004) both revisiting Paul Willis' (1977) classic Learning to Labour.

5.3 The young people's narratives collected by Pahl in the late 1970s were characterised more by a gritty realism than by romanticism. Precisely what impact the promotion in the intervening period of an equal opportunities agenda wrapped up in the rhetoric of chances of upward social mobility has had will be interesting to see. Equally interesting to explore will be the extent to which hard times generate nostalgic images among older people of the way things used to be. Pahl's cautions against 'pleasing nostalgia' (1984: 95) among older people and his speculations about how the world was changing for younger people 
are both highly pertinent to the re-visiting of Sheppey that we are currently undertaking as part of the HEFCE-funded South East Coastal Communities project.

5.4 We will also be learning from re-studies of other places. We will need to be mindful of how it is not only the world that changes, but also our perceptions of it. The first re-study of 'Middletown' by the Lynds (1937) picked up on the issue of local power that the initial study a decade earlier had missed. Many decades on, one of the most studied communities in the world is still revealing new sides (Lassiter et al 2004) (see also the recent BBC Radio Four Crossing Continents programme on Muncie (Hard Times in Middletown, USA) http://www.bbc.co.uk/programmes/b00jts6m).

\section{Conclusion}

6.1 Comparing how the current recession is playing out in one locality with how things were thirty years ago will undoubtedly reveal both changes and continuities, captured perhaps in the phrase 'the changing same'. How things unfold in one specific locality should not, of course, be taken as indicative of more general trends, but there is much that can be learned from such cases, both as re-studies and as points of comparison with research conducted elsewhere.

\section{References}

BAMBERGER, B. and Davidson, C. (1999) Closing: the life and death of an American factory. London: Norton.

BLUESTONE, B. and Harrison, B. (1982) The Deindustrialization of America: Plant Closing, Community Abandonment, and the Dismantling of Basic Industry, New York: Basic Books.

COWIE, J. and Heathcott, J. (eds.) (2003) Beyond the Ruins: The Meaning of Deindustrialisation , Ithaca: Cornell/ ILR.

DOLBY, N. and Dimitriadis, G. (eds.) (2004) Learning to Labor in New Times , London: Routledge/ Falmer.

DUDLEY, K.M. (1994) The End of the Line: Lost Jobs, New Lives in Postindustrial America , Chicago: Chicago University Press.

ELLIOTT, J. (2005) Using Narrative in Social Research: Qualitative and quantitative Approaches. London: Sage.

EZZY, D. (2001) Narrating Unemployment, Aldershot: Ashgate.

GLUCKSMANN, M. (1995) Why 'work'? Gender and the total social organisation of labour, Gender, Work and Organisation, 2, 2: 63-75.

GLUCKSMANN, M. (2006). 'Shifting boundaries and interconnections: extending the "total social organisation of labour"', in L. Pettinger, J. Parry, R.F. Taylor and M. Glucksmann (editors) A New Sociology of Work? Oxford and Malden, MA.: Blackwell Publishing/The Sociological Review.

GOODWIN, J. and O'Connor, H. (2005) 'Exploring complex transitions: looking back at the 'golden age' of youth transitions', Sociology, 39, 2: 197-200.

HALSEY, A. H. (2004) A History of Sociology in Britain: Science, Literature and Society. Oxford: Oxford University Press.

JAHODA, M., Lazarsfeld, P. and Zeisel, H. (1972) Marienthal: The sociography of an unemployed community. London: Tavistock.

LASSITER, L., Goodall, H., Campbell, E. and Johnson, M. (eds) (2004) The Other Side of Middletown: Exploring Muncie's African American Community. Walnut Creek CA: AltaMira Press.

LINKON, S. and Russo, J. (2002) Steeltown USA: Work and Memory in Youngstown. Lawrence: University of Kansas.

LOCKWOOD, D. (1975) 'Sources in variation in working-class images of society', in M. Bulmer (ed.) Working-class images of society. London: Routledge and Kegan Paul.

LORETTO, W., Vickerstaff, S. and White, P. (eds) (2007) The Future for Older Workers: New

Perspectives. Bristol: Policy Press. 
LUXTON, M. and Corman, J. (2001) Getting by in Hard Times: Gendered Labour at Home and on the Job , Toronto: University of Toronto Press.

LYND, R. and Lynd, H. (1937) Middletown in Transition: A study in cultural conflicts. New York: Harcourt, Brace and Co.

MARX, K. and Engels, F. (1973) 'Manifesto of the Communist Party' in K. Marx The Revolutions of 1848. Harmondsworth: Penguin.

MCDOWELL, L. (2003) Redundant Masculinities? Employment Change and White Working Class Youth, Oxford: Blackwell.

MILLS, C. W. (1970) The Sociological Imagination. Harmondsworth: Penguin.

PAHL, R. E. (1978) Living without a job: how school leavers see the future, New Society 2 November 1978 , pp.259-62.

PAHL, R. E. (1984) Divisions of Labour. Oxford: Basil Blackwell.

SALAMAN, G. (1974) Community and occupation: An exploration of work/ leisure relationships , Cambridge: Cambridge University Press.

SIMMEL, G. (1990) The Philosophy of Money. London: Routledge.

WALLACE, C. (1987) For Richer, For Poorer: Growing up in and out of work. London: Tavistock.

URRY, J. (2007) Mobilities. Cambridge: Polity Press.

WESTERGAARD, J. (1995) Who Gets What? The Hardening of Class Inequality in the Late Twentieth Century. Cambridge: Polity Press.

WILLIS, P. (1977) Learning to Labour: How Working Class Kids get Working Class Jobs Farnborough: Saxon House.

ZELIZER, V. (1997) The Social Meaning of Money: Pin Money, Paychecks, Poor Relief, and Other Currencies. Princeton, NJ: Princeton University Press. 